\title{
CARBON DISCLOSURE PRACTICES OF AEROSPACE AND AIRLINES COMPANIES: SUBSTANTIVE OR SYMBOLIC LEGITIMATION by Tarmizi Achmad
}

Submission date: 11-Apr-2018 01:09PM (UTC+0700)

Submission ID: 944801052

File name: and_Airlines_Companies_Substantive_or_Symbolic_Legitimation.doc (165.5K)

Word count : 4566

Character count: 26673 


\title{
CARBON DISCLOSURE PRACTICES OF AEROSPACE AND AIRLINES COMPANIES: SUBSTANTIVE OR SYMBOLIC LEGITIMATION
}

\author{
Faisal Faisal $^{1}$, Hasna Azizah Fithriani ${ }^{2}$ and Tarmizi Achmad ${ }^{3}$ \\ 1,2,3 Accounting Department, Faculty of Economics and Business, Universitas Diponegoro, \\ Semarang, Indonesia \\ IFaisal@undip.ac.id, ${ }^{2}$ hasna.azizahf17@gmail.com, ${ }^{3}$ t_achmad@yahoo.com.au
}

\begin{abstract}
This study investigates whether firms increase their carbon disclosure to gain the attention of stakeholder and whether the pattern of disclosure is symbolic or substantive. Content analysis of the annual and sustainability reports of forty-two aerospace, air courier and airlines companies listed on Forbes 2000 was conducted to measure and compare disclosure practices in 2011 and 2013. The descriptive statistics and Wilcoxon signed-rank test were carried out to answer the research questions. We found that firms do increase their carbon disclosure in sustainability reports only. In spite of the fact that previous studies have generally stated that disclosures have been used by corporations as a tool to legitimize their actions, the results of our study differ slightly. A more carbon-intensive industry such as aerospace, air courier and airlines has disclosed substantive information in relation to carbon. This study suggests that stronger requirements from regulators such as compliance obligations to disclose substantive information are most likely to make firms more accountable in their carbon disclosures. This result indicates that companies from this industry have made a substantial commitment to carbon reduction. This finding supports decision- makers, in particular regulators, to continue to institutionalize carbon regulation. It also provides empirical evidence of patterns of carbon disclosure in a specific industry.
\end{abstract}

Keywords: Carbon disclosures; legitimacy; impression management; content analysis

\section{INTRODUCTION}

Recently, an increasing number of stakeholders have been paying significant attention to firms' carbon disclosure. The emergence of legislation and mandatory reporting requirements in various countries have increased stakeholders' demands of firms to disclose their carbonproducing activities (Comyns \& Figge, 2015; Matisoff, Noonan \& O'Brien, 2013). To date, many companies have demonstrated an understanding of the need for the impacts of their operations on the environment, to be transparent and have, accordingly, committed to voluntary disclosure (Luo, Lan \& Tang, 2012). As reported by Pricewaterhouse Coopers (PWC), by 2013 membership of the Climate Disclosure Leadership Index (CDLI) of Global 500 corporations had increased from 94 per cent to 97 per cent, indicating companies the seriousness in disclosing carbon-related information (Pricewaterhouse Coopers, 2013). Although carbon disclosures made by companies are rising, in publishing information for their stakeholders regarding the carbon, firms' motivations vary, as does the information they disclose.

Ideally, a firm provides its reports in order to give clear and objective information about its resources and performance to stakeholders (Parker, 1982). Stakeholders then use these reports 
to evaluate a firm's performance, mostly by financial measurements, and to predict future performance and then make an investment decision. However, in reality, firms and stakeholders bring their own perceptions to performance information, especially the nonfinancial performance such as environmental performance. Studies suggest that firms' disclosures in reports serve a number of purposes, namely they are a mean of managing public impressions ${ }^{1}(\mathrm{Neu}$ et al., 1998, p. 280), a way of making a particular impression on a regulatory body (Luo et al., 2012) or a tool for ensuring that companies are "good" or "good enough" to be considered by stakeholders (Deegan, Rankin \& Tobin, 2002; O'Donovan, 2002). More recent studies argue that disclosures in areas such as global warming, greenhouse-gas emissions and issues relating to carbon footprint are often just normative and intended to reduce firms' environmental activities to potential scrutiny - that is, they may not be related to the actual environmental performance (Freedman \& Jaggi, 2011; Hrasky, 2012; Liesen, Hoepner, Patten \& Figge, 2015).

Since disclosure can materially affect both a firm's image and its stakeholders' decision making, it can also create a positive impression among stakeholders, without representing any real change in the company performance. This is referred to as symbolism. Conversely, a firm can make operational changes in accordance with the expectations of society, which demonstrate its behaviour management (Kim, Bach \& Clelland, 2007). Whether the disclosure of carbon-related activities is a form of management's impression to influence the stakeholders or a manifestation of genuine accountability, remains open to debate (Boiral, 2014), and whether environmental disclosure enhances corporate legitimacy, likewise remains unanswered (Kuo \& Chen, 2013). Therefore, further research on environmental disclosure is required (Hopwood, 2009). Among other things, such research should discern the meaning of various carbon disclosures, assess their quality and elucidate the motivations of management in making these disclosures (Wilmshurst \& Frost, 2000).

This study adopts and extends Hrasky's (2012) study by considering a limited industry sector, namely aerospace, air courier, and airlines, as listed in the Forbes 2000 in 2011 and 2013. This sector was selected for its relevance to the subject and because firms in the sector may likely be accurately reporting on their carbon-related activities. Carbon disclosure is important in the aerospace, air courier and airlines industry as it allows stakeholders to assess a firm's current environmental performance, especially, its ability in measuring the efforts of management to combat and limit the impact of air transport on climate change. Monitoring and assessing of carbon related (e.g. $\mathrm{CO}_{2}$ emissions, energy consumptions, fuels efficiency) may mitigate potential negative effects on environmental performance.

Focusing on one industry sector allows for the inclusion of industry-specific factors in the content analysis disclosure instrument (Comyns \& Figge, 2015). The research questions to be addressed are: RQ1: Has the amount of carbon disclosures by aerospace and airline firms increased? RQ2: What form (symbolic or substantive) of carbon disclosure is used by aerospace, air courier and airline firms?

\footnotetext{
${ }^{1} \mathrm{Neu}$, Warsame, and Pedwell (1998, p. 280) define impression management as "efforts to shape the impressions of relevant publics through the provision of environmental disclosures, but it says nothing about the "truth" or "falsity" of these disclosures". Hooghiemstra (2000, p. 60) defines impression management as "a field of study within social psychology studying how individuals present themselves to others to be perceived favourably by others."
} 


\section{LITERATURE REVIEW}

Firms' motivations for disclosing environmental information such as carbon use have been studied through a variety of theoretical perspectives and, among these, accountability theory and legitimacy theory have been widely employed (Barkemeyer, Comyns, Figge \& Napolitano, 2014). Accountability theory focuses on a societal view of reporting and the idea that firms have an obligation to provide accurate and reliable information to the public, who have the rights to know the validity of such information, to ensure that the firm's activities and policies are conforming to the values and beliefs of the stakeholders (Brennan \& Merkl-Davies, 2014; Gray, 2001). By contrast, legitimacy theory concentrates on a managerial perspective and supports the notion that environmental disclosure is a management tool used to legitimize the firm's activities, rather than a tool to inform its internal and external public about environmental performance (Barkemeyer et al., 2014; Deegan et al., 2002). Legitimacy theory has been commonly used as a framework to examine reasons for disclosing environmental information and impression management behaviors (Cen \& Cai, 2014).

Richardson (1985, p. 140) defines legitimacy as a quality of congruence between acts and social values. The social processes by which legitimacy is established or defended are called "legitimation" (Dowling \& Pfeffer, 1975). Legitimacy is not created by the organization. It is a common perception or assumption that the actions within an organization are desirable, proper and consistent with the society's norms, values, beliefs and widely held views (Suchman, 1995). Legitimacy theory focuses on the relationship between stakeholders and the firm, where the firm has an implicit contract that should be maintained with stakeholders (Deegan, 2002). The firm-stakeholder relationship is viewed as being strong. It is stakeholders who ascribe legitimacy to a firm, and they are doing this as a function of their perceptions. Thus, firms need to convince stakeholders that their operations are aligned with societal norms and values.From this, however, it can be inferred that the firms' disclosure practices do not necessarily reflect their nature. In other words, disclosures may merely be symbolic.

As to provide information to stakeholders, firms produce disclosure reports for several reasons. For example, firms have increasingly fulfilled their legal obligations to report financial and non-financial information to stakeholders not to convey their actual performance, but as a legitimacy-building exercise, which highlights their achievements and presents other favorable images of themselves (Al-Tuwaijri, Christensen \& Hughes, 2004; Ogden \& Clarke, 2005). In other words, in relation to corporate environmental disclosure, impression management "occurs when management selects information to display and presents that information in a manner that distorts readers' perceptions of corporate achievements". Therefore, environmental reports, as other corporate reports are tools of impression management that seek to create and project a preferred image or identity (Brennan

\& Merkl-Davies, 2014). Impression management is said to be "proactive" when it is designed to enhance a corporation's image. Alternatively, impression management is said to be "controlprotective" when it is used to protect an established image in which that image is under threat (Stanton, Stanton \& Pires, 2004).

\section{RQ 1: Has the amount of carbon disclosure increased over the time?}

Generally, firms will employ the means necessary to increase profits. To increase profits and bolster their impressions, firms seek to justify their actions in their reporting, be it in annual, sustainability or other stand-alone reports. Two of the immediate or most obvious ways of a 
firm influencing its stakeholders are by increasing the amount of disclosure it makes and by increasing the quality of this disclosure. Legitimacy theory explains that firms gain legitimacy by their stakeholders considering them to have done so. Prior research has found that most firms seek increased legitimacy by increasing the amount of disclosure (see, for example, Deegan \& Gordon, 1996; Deegan et al., 2002; Patten, 1992). These studies conclude that environmental disclosure practices increased over the periods examined, particularly for firms that had been associated with negative incidents or that had been prosecuted. However, Guthrie and Parker (1989) found that economic, social or political conditions or events do not motivate firms to disclose environmental information.

\section{$R Q$ 2: What form (symbolic or substantive) of carbon disclosure is used?}

As has been indicated, firms have their own motivations for providing information about their performance, as well as their own perceptions of the information they provide. This is the case for financial performance and non-financial performance, including environmental performance and social activities. As Hopwood (2009) stated, corporate disclosures have the potential to present the truth of environmental activities, but they also have the potential to be manipulative. These potentials arise because firms have the twin objectives of ensuring stakeholders judging them to be "good" organizations, while at the same time making profits. Sometimes, making a profit and creating and maintaining a good impression can be at odd. To gain both profits and impressions, firms seek to justify their actions in their annual, sustainability, or other stand-alone reports.

Hrasky (2012) stated that Australian firms tend to use symbolic approach, rather than behavioral management approach. Meanwhile, Deegan and Gordon (1996) argued that the firms' environmental disclosure practices are self-laudatory (impression management). They mentioned that firms proposed positive things of their environmental performance, but fail to disclose the negative things. As suggested by O'Donovan (2002), it has been considered that the information content of carbon disclosures in the annual reports is more general than other types of reports (e.g. in sustainability report, media releases, or other integrated stand-alone environmental reports).

\section{RESEARCH METHODS}

The samples of the study comprise all firms included in the aerospace, air courier, and airlines industries listed in Forbes 2000 in 2011 and 2013. Forbes 2000 was selected because it has been considered as a reliable source. The samples adequately represent major firms from different countries and industries, including firms from the airlines and aerospace industries that have reported their carbon footprints. The carbon emissions, carbon footprints and other climate change effects of firms in the industry are immense, which was one reason why the industry was selected. The Air Transport Action Group reported that in 2013 the global aviation industry produced around $2 \%$ of the world's $\mathrm{CO}_{2}$ emissions and flights created 705 million tonnes of carbon dioxide emissions. Samples were selected using the purposive sampling method, as to provide criteria that can determine the kind of samples that will be suitable. The 2013 were selected as they represented the current conditions when the study was conducted. In addition, the 2013 was also the year in which Pricewaterhouse Coopers published the Climate Disclosure Leadership Index (CDLI) survey. As the focus of this study is to compare the disclosure over time, the interval of two years may help described the pattern of disclosure. 
Table 1: Sample Selection

\begin{tabular}{|l|c|}
\hline \multicolumn{1}{|c|}{ Criteria } & Number \\
\hline Aerospace, air courier, and airlines industries of Forbes 2000 in 2011 \& 2013 & 47 \\
Companies which didn't have a rank in 2013 & $(3)$ \\
Companies which didn't have a rank in 2011 & $(2)$ \\
Final sample & 42 \\
\hline
\end{tabular}

Table 2: The Disclosure Categories

\begin{tabular}{|c|c|c|}
\hline Disclosure type & Description & Exemplifying disclosure \\
\hline \multicolumn{3}{|l|}{ Symbolic: } \\
\hline $\begin{array}{l}\text { 1. Normative } \\
\text { statement }\end{array}$ & $\begin{array}{l}\text { Statements espousing commitment } \\
\text { to and recognition of the importance } \\
\text { of carbon footprint, global warming } \\
\text { and climate change but not } \\
\text { indicative of specific action or } \\
\text { outcome. }\end{array}$ & $\begin{array}{l}\text { Climate change and resource scarcity are } \\
\text { issues that require us to evolve our } \\
\text { business model to meet our } \\
\text { responsibilities. }\end{array}$ \\
\hline $\begin{array}{l}\text { 2. Aspirational } \\
\text { target }\end{array}$ & $\begin{array}{l}\text { Articulation of targets or objectives } \\
\text { to be achieved in the future without } \\
\text { associated action. }\end{array}$ & $\begin{array}{l}\text { Our ultimate goal is to have no carbon } \\
\text { emissions released to the atmosphere. }\end{array}$ \\
\hline $\begin{array}{l}\text { 3. Awards or } \\
\text { recognition }\end{array}$ & $\begin{array}{l}\text { Statements indicating external } \\
\text { recognition of positive efforts } \\
\text { pertinent to carbon footprint, global } \\
\text { warming and climate change. } \\
\end{array}$ & $\begin{array}{l}\text { We were included in the } 2004 \text { Climate } \\
\text { Leadership Index comprising the } 50 \text { "best } \\
\text { in-class" responses. }\end{array}$ \\
\hline \multicolumn{3}{|l|}{ Substantive: } \\
\hline $\begin{array}{l}\text { 4. Internal } \\
\text { activities }\end{array}$ & $\begin{array}{l}\text { Statements on specific internal } \\
\text { corporate actions taken relevant to } \\
\text { carbon footprint, global warming } \\
\text { and climate change. }\end{array}$ & $\begin{array}{l}\text { The \$A30 million plant that we opened in } \\
\text { September will generate approximately } \\
\text { six mega watts of electricity per hour and } \\
\text { reduce greenhouse gas emission by } \\
250,000 \text { tonnes of carbon dioxide } \\
\text { equivalent per year. }\end{array}$ \\
\hline $\begin{array}{l}\text { 5. External } \\
\text { activities }\end{array}$ & $\begin{array}{l}\text { Statements on involvement in } \\
\text { activities relevant to carbon } \\
\text { footprint, global warming and } \\
\text { climate change that are initiatives } \\
\text { developed with partners or projects } \\
\text { external to the organisation. }\end{array}$ & $\begin{array}{l}\text { Since becoming a member of the } \\
\text { Greenhouse Challenge Program, one } \\
\text { division has completed a range of } \\
\text { efficiency improvement projects resulting } \\
\text { in reduced greenhouse gas emissions of } \\
\text { more than one million tonnes per annum. }\end{array}$ \\
\hline $\begin{array}{l}\text { 6. Assisting } \\
\text { others }\end{array}$ & $\begin{array}{l}\text { Statements onactions taken to help } \\
\text { others to reduce their carbon } \\
\text { footprint. }\end{array}$ & $\begin{array}{l}\text { We have developed a range of products } \\
\text { so that customers have a choice about } \\
\text { their contribution to greenhouse gas } \\
\text { emissions reduction. }\end{array}$ \\
\hline $\begin{array}{l}\text { Descriptive } \\
\text { Statements }\end{array}$ & $\begin{array}{l}\text { Statements of fact about the } \\
\text { company and/orits operations that do } \\
\text { not describe specific action taken to } \\
\text { reduce environmental impact. }\end{array}$ & $\begin{array}{l}\text { The average } \mathrm{CO}_{2} \text { emissions from our } \\
\text { vehicle fleet is } 9.2 \mathrm{CO}_{2} \text { per vehicle. } \\
\text { In } 2008,32 \text { percent of greenhouse gas } \\
\text { emissions were } \mathrm{CO}_{2} \text { and } 68 \text { percent were } \\
\text { N2O. }\end{array}$ \\
\hline Other & $\begin{array}{l}\text { General statements, not company } \\
\text { specific related to carbon footprint, } \\
\text { global warming and climate change. }\end{array}$ & $\begin{array}{l}\text { Tonnes and tonnes, methane gas } \\
\text { produced by landfills and other activities, } \\
\text { which has a global warming potential } 21 \\
\text { times higher than carbon dioxide. }\end{array}$ \\
\hline
\end{tabular}


The type of data used in the study is the secondary data. The study used annual and sustainability reports. Using annual and sustainability reports to evaluate the pattern of carbon disclosure, rather than using a single report type, provided a more comprehensive picture of aerospace, air courier, and airlines' disclosure practices (Van Staden \& Hooks, 2007). Analysis was restricted to printed reports only because it was impossible to discover what information would have been attainable on firms' websites in 2011 and 2013, or referring back to these two years, but published in later years. This is notwithstanding the fact that on their websites, firms made huge amount of information about their carbon footprint availability (Hrasky, 2012). In order to measure the type of disclosure (substantive or symbolic), content analysis was employed. Specifically, the meaning of the text in annual and sustainability reports was assessed. The content analysis procedure provided researchers with a systematic way of codifying and classifying large amounts of unstructured text and allowed them to highlight patterns of disclosures and any changes in these over time (Hooks \& Van Staden, 2011; Soobaroyen \& Ntim, 2013). However, there are a number of limitations in undertaking content analysis: the most significant one is the risk of inconsistent interpretation of what it is that is being measured (Wilmshurst \& Frost, 2000, p. 17). To minimize this risk, our study employed two independent researchers who are experts in corporate social environmental studies.

The unit of analysis of the study was the number of pages. This unit was adopted for two reasons. First, pages expressed the total amount of space given to a topic, reflecting its relative importance. Second, pages were the easiest unit to measure by hand (Gray, Kouhy \& Lavers, 1995). To avoid any subjectivity and ambiguity in calculating the extent of the disclosures, images were excluded.

Table 2 presents the four categories of disclosures that were identified: symbolic, substantial, descriptive and other. Normative statements, aspirational targets and awards/recognition statements were the types of information referred as symbolic. While the three types of information used to capture substantive disclosures were internal activities, external activities, and statements about assisting others. Descriptive and 'other' statements accounted for the remainder of disclosures. The descriptive statistics and Wilcoxon signed-rank test were employed to answer the research questions.

\section{RESULTS AND DISCUSSION}

\section{RQ1: Has the amount of carbon disclosure increased over the time?}

The results of the descriptive statistics analysis are presented in Table 3. For the symbolic category in annual reports in both years, normative statements are the type of information disclosed most often (a mean of 1.5 pages per report in 2011 and 1.3 pages in 2013), followed by aspirational targets and awards/recognition respectively for both years. In the substantive category, internal activities are the information type most often communicated. Overall, the substantive category had the highest number of pages per annual report.

Panel A shows that the total disclosure in annual reports decreased from 9.5 pages per report in 2011 to 9.1 in 2013. This decrease occurred in most categories, the exception being awards/recognition, external activities and descriptive statements - the latter increase being despite decreasing overall disclosure for the symbolic and substantive categories. Based on these results it can be concluded that there was a more substantive disclosure in both years. 
Panel B shows that the total disclosure in sustainability reports increased from 21.3 in 2011 to 24.3 pages in 2013. Symbolic information increased from 5.7 pages per report in 2011 to 6.3 pages in 2013 and substantive information disclosed raised from 6.9 to 9.2 pages across the same years. This increase in the disclosure of both symbolic and substantive information is inconsistent with the finding of Hrasky (2012), who found that only symbolic carbon-related information increased.

Table 3: Descriptive Statistics of Disclosure Categories Based on Media

\begin{tabular}{|c|c|c|c|c|c|c|c|}
\hline \multirow{2}{*}{\begin{tabular}{|l|} 
Panel A: Annual reports \\
Disclosure categories \\
\end{tabular}} & \multirow[b]{2}{*}{$\mathrm{N}$} & \multicolumn{2}{|c|}{2011} & \multicolumn{2}{|c|}{2013} & \multicolumn{2}{|c|}{$\begin{array}{c}\text { Wilcoxon signed- } \\
\text { rank test }^{2} \\
\end{array}$} \\
\hline & & Mean $^{1}$ & $\mathrm{SD}$ & Mean & SD & $\mathrm{Z}$ & Sig. \\
\hline 1.Normative statement & 42 & 1.489 & 1.9986 & 1.298 & 1.5592 & -.651 & .515 \\
\hline 2.Aspirational target & 42 & .915 & 1.7795 & .574 & 1.2810 & -1.992 & $.046^{* * * 4}$ \\
\hline 3.Awards/recognition & 42 & .191 & 3977 & .362 & .6402 & -1.734 & $.083 *$ \\
\hline Total Symbolic $(1+2+3)$ & 42 & 2.595 & 3.3729 & 2.234 & 2.5556 & -.998 & .318 \\
\hline 4.Internal activities & 42 & 1.957 & 2.6040 & 1.553 & 2.2632 & -1.394 & .163 \\
\hline 5.External activities & 42 & .617 & 1.0745 & .702 & 1.2839 & -.417 & .677 \\
\hline 6.Assisting others & 42 & .319 & 1.0448 & .149 & .4653 & -1.136 & .256 \\
\hline Total Substantive $(4+5+6)$ & 42 & 2.893 & 3.5767 & 2.404 & 2.9241 & -1.087 & .277 \\
\hline 7.Descriptive statements & 42 & 1.936 & 2.9957 & 2.410 & 3.0995 & -.285 & .776 \\
\hline 8.Other & 42 & 2.085 & 3.4252 & 2.043 & 3.8615 & -1.025 & .306 \\
\hline Total Disclosure $(1-8)$ & 42 & 9.509 & 10.9463 & 9.091 & 8.9265 & -.977 & .329 \\
\hline \multicolumn{8}{|l|}{ Panel B: Sustainability reports } \\
\hline 1.Normative statement & 42 & 3.213 & 5.7330 & 2.957 & 4.3736 & -.535 & .593 \\
\hline 2.Aspirational target & 42 & 1.787 & 3.2633 & 2.319 & 3.5084 & -1.178 & .239 \\
\hline 3.Awards / recognition & 42 & .702 & 1.6929 & 1.043 & 1.8761 & -1.193 & .233 \\
\hline Total symbolic $(1+2+3)$ & 42 & 5.702 & 9.9781 & 6.319 & 8.4083 & -1.287 & .198 \\
\hline 4.Internal activities & 42 & 3.383 & 5.1184 & 5.064 & 6.8791 & -2.115 & $.034 * *$ \\
\hline 5.External activities & 42 & 2.489 & 4.0800 & 3.085 & 4.5245 & -.851 & .395 \\
\hline 6.Assisting others & 42 & 1.106 & 2.3796 & 1.085 & 2.3759 & -.142 & .887 \\
\hline Total substantive $(4+5+6)$ & 42 & 6.978 & 9.3959 & 9.234 & 11.5103 & -1.946 & $.052 *$ \\
\hline 7.Descriptive statements & 42 & 6.064 & 13.0591 & 5.660 & 9.3000 & -.022 & .983 \\
\hline 8.Other & 42 & 2.511 & 4.9645 & 3.064 & 5.1769 & -.953 & .341 \\
\hline Total disclosure $(1-8)$ & 42 & 21.255 & 34.0514 & 24.277 & 30.0259 & -1.308 & .191 \\
\hline \multicolumn{8}{|c|}{$\begin{array}{l}\text { Notes: } \\
{ }^{* *} \text { Difference between } 2013 \text { and } 2011 \text { is significant at } 5 \% . \\
\text { *Difference between } 2013 \text { and } 2011 \text { issignificant at } 10 \% . \\
{ }^{1} \text { Mean number of pages } \\
{ }^{2} \text { This study used Saphiro-Wilktest to assess the normality of the data as the sample size is small (42). } \\
\text { The result of normality test showed that the data certainly are not normally distributed; therefore, the } \\
\text { Wilcoxon signed-ranks test was run. }\end{array}$} \\
\hline
\end{tabular}

Comparing panels $\mathrm{A}$ and $\mathrm{B}$, the results show that the mean of carbon information disclosed in sustainability reports is higher than in annual reports. This result is in line with the findings of the 2013 survey of KPMG, which indicated a year on year increase in firms using sustainability reports to report on social responsibility and environmental disclosure. Barkemeyer et al. (2014) suggests that the qualitative carbon-related information presented in 
the sustainability report is more comprehensive than in the annual report which might account for this trend. In a similar vein, Frost, Jones, Loftus, and Van Der Laan (2005) indicate that the annual report provides very limited information on variations and indicators related to corporate social environmental information. Furthermore, Kuasirikun and Sherer (2004, p.

629) contend that, compared to sustainability reports, corporate annual reports may not be as a full representation or communication of firms'overall social and environmental performance.

\section{$R Q$ 2: What form (symbolicor substantive) of carbon disclosure is used?}

Table 4 displays the proportion of disclosure by type of reporting media. Proportional disclosure explains each set of categories. Symbolic information represents the sum of normative statements, aspirational targets, and awards or recognition. Substantive or behavioural management represents the sum of internal activities, external activities, and assisting others. The total disclosure represents the sum of symbolic, substantive (behavioural), descriptive statements, and other information. Based on Table 4, the proportion of symbolic information in annual reports decreased, from 27.3 per cent (2011) to 24.6 per cent (2013). As with symbolic disclosure, substantive disclosure also declined from 30.4per cent (2011) to 26.4 percent (2013). However, the proportion of carbon disclosure in the descriptive category increased from 20.4 per cent (2011) to 26.5 per cent (2013); likewise disclosure in the other category increased from 21.9 per cent (2011) to 22.5 per cent (2013). As for sustainability reports, the proportion of symbolic carbon-related disclosure decreased from 26.8 per cent (2011) to 26.0 (2013). Likewise, the disclosure of descriptive information decreased, whereas the 'other' information category showed a slight decrease. The disclosure of substantive carbon-related information, however, increased from 32.8 per cent (2011) to 38.0 per cent (2013).

Given the results of Wilcoxon signed-rank tests for all categories being not significant, these findings suggest that the aerospace, air courier and airlines companies tend to use symbolic and substantive information to improve their environmental legitimacy. According to the tenets of legitimacy, the decreasing symbolic disclosure both in annual and sustainability reports may be a signal of a firm's intention to change its carbon disclosure from symbolic to substantive. The choice to adopt the substantive disclosure strategy, especially using media sustainability reports to convey not only a firm's favorable performance, but also to manage specific stakeholders' perceptions that aerospace, air courier, and airlines companies are compliant and accountable, indicates firms' view that this strategy could maintain their long-term legitimacy. In this study, we found some evidences of behavioural management in sustainability reports. For example, Singapore Airlines and Boeing provided substantive information such as external activities and assisting others.

We are a member of the Sustainable Aviation Fuel Users Group (SAFUG), which is focused on accelerating the development and commercialization of sustainable aviation fuels. Currently, SAFUG represents approximately 32 per cent of commercial aviation fuel demand. As a member of SAFUG, SIA has pledged to advance and adopt aviation biofuels produced in a sustainable manner that exhibit minimal impact on biodiversity and meet a sustainability standard with respect to land, water, and energy use (Singapore Airlines, 2013, p. 34).

As the world's leading aerospace company, Boeing plays a major role in helping the commercial aviation industry in achieving its goals of carbon-neutral growth from 2020 and a 50 percent reduction in carbon emissions by 2050 (Boeing, 2013, p. 16). 
Table 4: Proportional of Disclosure Based on Media Reporting

\begin{tabular}{|l|c|c|c|c|}
\hline \multirow{2}{*}{ Disclosure categories } & \multicolumn{3}{c|}{ Proportionate disclosure in media (in percentages) } \\
\cline { 2 - 5 } & Annual reports & \multicolumn{2}{c|}{ Sustainability reports } \\
\cline { 2 - 5 } & 2011 & 2013 & 2011 & 2013 \\
\hline Symbolic information & 27.3 & 24.6 & 26.8 & 26.0 \\
Substantive (behavioural) information & 30.4 & 26.4 & 32.8 & 38.0 \\
Descriptive statements & 20.4 & 26.5 & 28.5 & 23.3 \\
Other & 21.9 & 22.5 & 11.8 & 12.6 \\
Total & 100.0 & 100.0 & 100.0 & 100.0 \\
\hline Notes: The results of the Wilcoxon signed-rank tests for all disclosure categories showed that there were \\
no statistically significant difference between 2011 and 2013 for both annual and sustainability reports. \\
\hline
\end{tabular}

\section{CONCLUSION}

This study analyzes the firms' disclosure of carbon-related information for the years 2011 and 2013. Based on a sample of forty-seven, it was found that the firms did increase their carbon disclosure, but in sustainability reports only. The carbon disclosure practices in the annual reports tended to be symbolic, whereas in the sustainability reports, these were mostly substantive, which is consistent with the behavioural management approach. The results also provide some support to the accountability and legitimacy perspectives, which suggest that firms use carbon disclosure in an attempt to justify their actions and convey a sense of accountability to their stakeholders. Practically, this study suggests that stronger requirements from regulators such as compliance obligations to disclose substantive information are most likely to make firms more accountable in their carbon disclosures. The implication of this study is that the government being a policy maker, needs to encourage companies intensively to disclose substantive information in relation to carbon. Our research found that carbon disclosure in the annual report is still symbolic. This result may need to be taken into consideration for regulators to harmonize the content-type of information that must be disclosed by the company.

Our study has several limitations. Even though a global sample of firms was used, only one industry was considered, namely aerospace, air courier and airlines. Therefore, the study's predictive ability for other industries was limited, that is whether or not these industries would demonstrate the same results or tendencies. Second, a high level of judgement was required to ascertain how sentences were to be categorized (as normative statements, aspirational targets, and so on). Firms sometimes made several types of disclosures in a single sentence, which meant these sentences carried multiple meanings. Therefore, the study involved the subjective judgments of the researchers. 
CARBON DISCLOSURE PRACTICES OF AEROSPACE AND AIRLINES COMPANIES: SUBSTANTIVE OR SYMBOLIC LEGITIMATION

ORIGINALITY REPORT

$\%$

SIMILARITY INDEX
$\%$

INTERNET SOURCES

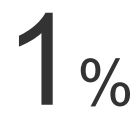

PUBLICATIONS
$\%$

STUDENT PAPERS

PRIMARY SOURCES

1 Irene Pollach. "Issue Cycles in Corporate Sustainability Reporting: A Longitudinal Study", Environmental Communication, 2016 Publication

2 R. P. Gephart. "The Organizational Basis of Industrial Accidents in Canada", Journal of Management Inquiry, 09/01/1993 Publication

\section{3}

Richard H. Moore, Michael Shook, Andreas Beyersdorf, Chelsea Corr et al. "Influence of Jet Fuel Composition on Aircraft Engine Emissions: A Synthesis of Aerosol Emissions Data from the NASA APEX, AAFEX, and ACCESS Missions", Energy \& Fuels, 2015 Publication

Brooks, K.P., L.J. Snowden-Swan, S.B. Jones, M.G. Butcher, G.-S.J. Lee, D.M. Anderson, J.G. Frye, J.E. Holladay, J. Owen, L. Harmon, F. Burton, I. Palou-Rivera, J. Plaza, R. Handler, and D. Shonnard. "Low-Carbon Aviation Fuel Through the Alcohol to Jet 
Pathway", Biofuels for Aviation, 2016.

Publication

5 Jose Maria Gonzalez Gonzalez, Constancio

Zamora Ramírez. "Organisational

communication on climate change",

International Journal of Climate Change

Strategies and Management, 2016

Publication

6 Bikki Jaggi, Alessandra Allini, Riccardo

Macchioni, Claudia Zagaria. "The Factors

Motivating Voluntary Disclosure of Carbon

Information: Evidence Based on Italian Listed

Companies", Organization \& Environment,

2017

Publication

Exclude quotes

Off

Exclude matches

Off

Exclude bibliography Off 
CARBON DISCLOSURE PRACTICES OF AEROSPACE AND AIRLINES COMPANIES: SUBSTANTIVE OR SYMBOLIC LEGITIMATION

\section{GRADEMARK REPORT}

FINAL GRADE

10

PAGE 1

PAGE 2

PAGE 3

PAGE 4

PAGE 5

PAGE 6

PAGE 7

PAGE 8

PAGE 9
GENERAL COMMENTS

Instructor 